\title{
Effect of adrenal steroids on insulin release from cultured rat islets of Langerhans
}

\author{
J. Pierluissi, F.O. Navas and S.J.H.Ashcroft ${ }^{1}$ \\ Department of Physiology, Vargas School of Medicine, Universidad Central de Venezuela, Caracas, Venezuela and \\ ${ }^{1}$ Nuffield Department of Clinical Biochemistry, John Radcliffe Hospital, Headington, Oxford, UK
}

\begin{abstract}
Summary. The effect of additions to the culture medium of some natural or synthetic corticosteroid hormones was studied in cultured rat islets of Langerhans. The steroids decreased glucose-induced insulin release. The extent of inhibition by dexamethasone was $18-55 \%$, prednisolone $23 \%$, hydrocortisone $21 \%$ and aldosterone $18 \%$. None of them affected the basal secretion of insulin or had any effect on diameter or insulin content of the islet. The inhibitory action of dexamethasone on insulin release was observed in the range $63 \mathrm{nmol} / 1$ to $6.3 \mu \mathrm{mol} / 1$. At $6.3 \mu \mathrm{mol} / 1$ during two $h$, dexamethasone (a) inhibited insulin response to glucose concentrations above
\end{abstract}

$5 \mathrm{mmol} / 1$ (b) caused a delay in the first phase and markedly reduced the second phase of insulin release of perifused islets, and (c) decreased the incorporation of $\left[\mathrm{H}^{3}\right]$-leucine into total islet proteins without affecting $\left[\mathrm{H}^{3}\right]$-leucine-incorporation into insulin plus proinsulin. It is suggested that steroids, by directly acting on the islets of Langerhans, may modulate the insulinrelease response to secretagogues.

Key words: Insulin release, insulin biosynthesis, dexamethasone, prednisolone, hydrocortisone, aldosterone, cultured islets.
Direct inhibitory effects of corticosterone on insulin secretion from the perfused rat pancreas and isolated islets have been shown $[1,2]$. However, direct effects of other adrenal steroid hormones have not been explored. We now report effects of dexamethasone, prednisolone, hydrocortisone and aldosterone on insulin release and biosynthesis in islets directly exposed to these steroids in culture.

\section{Materials and methods}

Islets were obtained by collagenase digestion [3] from pancreas of male, fed Sprague-Dawley rats $(200-300 \mathrm{~g})$. Batches of 50 islets were cultured in $5 \mathrm{ml}$ medium for 2 days with change to fresh medium at $24 \mathrm{~h}$. The culture medium was RPMI 1640 (Gibco, Grand Island, NY, USA) containing glucose $(11 \mathrm{mmol} / \mathrm{l})$, penicillin $(0.1 \mathrm{mg} / \mathrm{ml})$, streptomycin $(0.1 \mathrm{mg} / \mathrm{ml})$ and $10 \%(\mathrm{v} / \mathrm{v})$ inactivated calf serum (Gibco). The $\mathrm{pH}$ was buffered at 7.4 with $\mathrm{N}$-2-hydroxyethyl piperazine$\mathrm{N}^{\prime}$-2-ethane sulphonate (Hepes) $25 \mathrm{mmol} / \mathrm{l}$. The islets were carefully matched for size, and the cultures were maintained in a metabolic incubator at $37^{\circ} \mathrm{C}$ in an atmosphere of humidified air: $\mathrm{CO}_{2}$ (95:5). After $48 \mathrm{~h}$ in culture, the medium was supplemented with the steroid or solvent solution as described. Sodium phosphate salts of dexamethasone (Merck, Sharpe \& Dohme, Rayway, NJ, USA), prednisolone (Merck, Sharpe \& Dohme) and hydrocortisone (Sigma, St. Louis, MO, USA) were dissolved in an aliquot of the culture medium. The sodium hemisuccinate salt of aldesterone (Sigma) was solubilized in the culture medium with $10 \%(\mathrm{v} / \mathrm{v})$ ethanol; ethanol was also added to the matched control medium. After exposure, treated and control islets were used for the measurement of the various parameters. For insulin release, batches of five islets were preincubated for $30 \mathrm{~min}$ at $37^{\circ} \mathrm{C}$ in bicarbonate medium $\mathrm{pH} 7.4$ [4] containing fatty acid-free albumin (Sigma) $2 \mathrm{mg} / \mathrm{ml}$ and glucose $2 \mathrm{mmol} / 1$ followed by removal of the medium. The islets were then incubated for $2 \mathrm{~h}$ in the same medium containing glucose at the stated concentrations. Insulin released into the medium was measured by radioimmunossay [5] using rat insulin standard supplied by Novo Research Laboratories, Copenhagen, Denmark. Islets were also perifused as described previously [6] in two chambers run in parallel, each containing 100 treated or control islets. The perifusate was assayed for insulin release [5]. For insulin content, treated or control islets in batches of 5 were transferred from the culture medium and extracted in $0.5 \mathrm{ml} 0.154 \mathrm{~mol} / 1 \mathrm{NaCl} \mathrm{pH} 2$, containing bovine serum albumin $(2 \mathrm{mg} / \mathrm{ml})$, by sonication $(15 \mathrm{~s}$ at position 2 on a Fisons Soniprep 150). The sonicate was diluted and assayed for insulin [5]. Islet diameter of treated and control islets was measured in the same culture dish using an eye-piece micrometer in a Nikon stereoscopic dissecting microscope. For measurement of insulin plus proinsulin and total islet protein synthesis, treated and control islets in batches of 7 were incubated in bicarbonate medium containing glucose $(20 \mathrm{mmol} / \mathrm{l})$, albumin $(2 \mathrm{mg} / \mathrm{ml})$ and $\left[4,5-{ }^{3} \mathrm{H}\right]$-leucine $(4 \mu \mathrm{Ci}$, $50 \mathrm{Ci} / \mathrm{mmol}$ ) at $37^{\circ} \mathrm{C}$ for $90 \mathrm{~min}$. The incorporation of $\left[{ }^{3} \mathrm{H}\right]$-leucine into insulin plus proinsulin was measured using insulin-binding affinity columns and into total islet protein by trichoroacetic acid precipitation as previously described [7]. The results are expressed as mean \pm SEM for the number of separate batches of islets given in parenthesis. The statistical significance was assessed by the two-tailed Student's ttest.

\section{Results}

The time course of the effect of dexamethasone $(6.3 \mu \mathrm{mol} / 1)$ on insulin release is shown in Table 1-A. No effect was found on insulin release at glucose 
Table 1. Effect of dexamethasone on insulin release by cultured rat islets

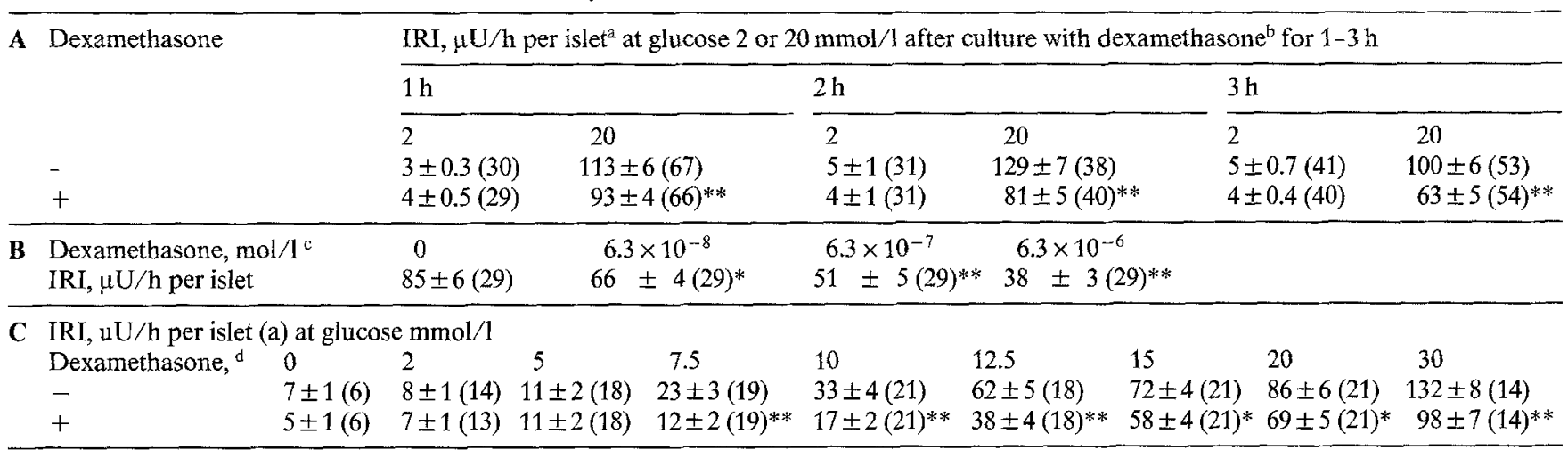

a Rates of insulin release (IRI) are given as mean \pm SEM for the number of observations shown in parenthesis.

b $6.3 \mu \mathrm{mol} / \mathrm{l}$ in culture medium

c At glucose $20 \mathrm{mmol} / \mathrm{l}$ for $2 \mathrm{~h}$

d $6.3 \mu \mathrm{mol} / 1$ for $2 \mathrm{~h}$

Statistical significance from control: $+p<0.05, * p<0.01, * * p<0.001$

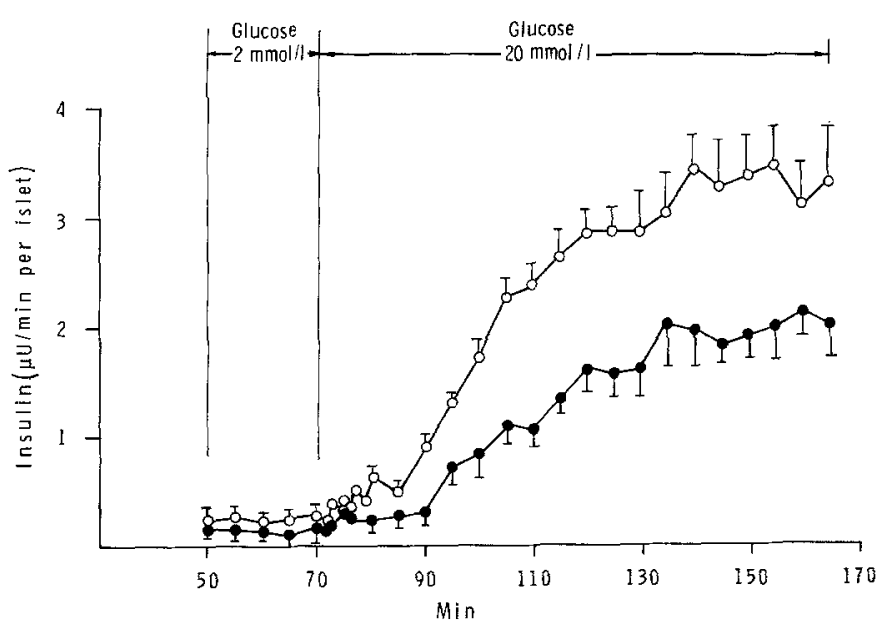

Fig. 1. Effects of dexamethasone on insulin response to glucose of perifused rat islets. After culture for 2 days, the islets were cultured for $2 \mathrm{~h}$ in the presence $(O)$ or in the absence $(O)$ of dexamethasone $(6.3 \mu \mathrm{mol} / 1)$. Results are given as mean \pm SEM of 5 experiments. Difference of rates of insulin release at $2 \mathrm{mmol} / \mathrm{l}$ glucose were not statistically significant $(p>0.05)$. The differences of rates of insulin release at $20 \mathrm{mmol} / 1$ glucose were statistically significant between $80 \mathrm{~min}$ and $170 \mathrm{~min}$ at $p<0.05$ to $p<0.001$.

$2 \mathrm{mmol} / \mathrm{l}$, while the response to glucose $20 \mathrm{mmol} / 1$ was inhibited by $18 \%$ in islets previously cultured with dexamethasone for $1 \mathrm{~h}$ and by $37 \%$ after 2 and $3 \mathrm{~h}$. Treatment of cultured islets for $2 \mathrm{~h}$ with 3 different concentrations of dexamethasone (Table 1-B) showed a doserelated reduction of insulin secretion in response to glucose $20 \mathrm{mmol} / 1$ to a maximum of $55 \%$ inhibition at dexamethasone $6.3 \mu \mathrm{mol} / 1$. Study of the effects of dexamethasone treatment $(6.3 \mu \mathrm{mol} / 1$ for $2 \mathrm{~h})$ on the response of islets to varying concentrations of glucose (Table 1-C) indicated that exposure to the steroid caused significant inhibition of the insulin release evoked by glucose at concentrations from 7.5 -
$30 \mathrm{mmol} / \mathrm{l}$. The treatment had no effect on the estimated $\mathrm{Km}$ for glucose $(14 \mathrm{mmol} / \mathrm{l})$ but decreased the $V_{\max }$ from 132 to $98 \mu \mathrm{U} / 1$ per islet $(p<0.001)$. In the perifusion system, dexamethasone pretreatment of the islets in culture $(6.3 \mu \mathrm{mol} / 1,2 \mathrm{~h})$ did not change the basal rate of insulin secretion. The response to glucose $20 \mathrm{mmol} / 1$ was delayed and markedly reduced in both the early and late phases (Fig. 1). The integrated stimulated area was decreased from $211 \pm 18$ to $117 \pm 15 \mu \mathrm{U}$ per islet $(\mathrm{df}=8, p<0.005)$. Dexamethasone $(6.3 \mu \mathrm{mol} / \mathrm{l}, 2 \mathrm{~h}) \mathrm{re}-$ duced the incorporation of $\left[{ }^{3} \mathrm{H}\right]$-leucine into total proteins of the islets by $7 \%$, from the control value of $16449 \pm 174(n=56)$ to $15454 \pm 174(n=56) \mathrm{dpm} /$ 90 min per islet $(p<0.001)$, but had no effect on $\left[{ }^{3} \mathrm{H}\right]$ leucine incorporation into insulin plus proinsulin. The duration of the effect of dexamethasone on insulin response to glucose was investigated after transferring the islets to fresh culture medium in the absence of added substances at the end of the $2 \mathrm{~h}$ treatment. The response to glucose $20 \mathrm{mmol} / 1$ was studied at 0,2 and $4 \mathrm{~h}$ of reculture. The secretory response to glucose was lowered by $27 \%$ at $0 \mathrm{~h}$, by only $10 \%$ at $2 \mathrm{~h}$ and was fully re-established at $4 \mathrm{~h}$.

The effect of dexamethasone $(6.3 \mu \mathrm{mol} / \mathrm{l}, 2 \mathrm{~h})$ on insulin release was compared in parallel experiments to those of equimolar concentrations of prednisolone and hydrocortisone and also to the effect of aldosterone $(8 \mathrm{nmol} / 1)$; these concentrations of hydrocortisone and aldosterone were ten times the upper physiological human plasma levels. There was no effect of these steroids on basal insulin secretion. The response to glucose $20 \mathrm{mmol} / \mathrm{l}$, as percent of control, was decreased $28.6 \pm$ $1.4(n=56)$ by dexamethasone, $22.5 \pm 1.4(n=31)$ by prednisolone, $21.0 \pm 1.3(n=40)$ by hydrocortisone and $17.8 \pm 1.3(n=36)$ by aldosterone. There was no effect of the tested steroids on insulin content or diameter of the islet. 


\section{Discussion}

The results show a consistent inhibition of glucose-stimulated insulin release from islets treated directly with dexamethasone, prednisolone, hydrocortisone and aldosterone without affecting the basal secretion of insulin. The effect was observed at a concentration of dexamethasone $(6.3 \mu \mathrm{mol} / \mathrm{l})$ equivalent to "pathophysiological' concentration of cortisol and also at a much lower concentrations within the 'physiological' range $(6.3 \mathrm{nmol} / 1)$. We also found similar inhibitory actions of hydrocortisone and prednisolone at physiological levels (results not shown). These findings are of interest since glucose intolerance is commonly associated with excessive secretion of cortisol and aldosterone and also with the therapeutic administration of dexamethasone or prednisolone. This reduced tolerance and the reduction of insulin secretion by steroids may be causally related. We have shown here that the acute effects of dexamethasone on islets are reversible. The effects of a more prolonged treatment are unknown.

Dexamethasone had no effect on insulin plus proinsulin biosynthesis and on insulin content of the islets. It apparently exerts its effect by impairing the capacity for release of insulin from a previously synthesized store. It is possible that the decreased insulin response to glucose may be mediated by impairment of islet glucose metabolism since glucocorticoids have been shown to diminish glucose uptake and oxidation in other tissues [8]. However, this may not be the sole cause of impaired insulin release; corticosterone treatment of perifused islets has been shown to decrease calcium inflow associated with insulin release mediated by leucine and non-nutrients carbamylcholine and gliclazide [9], suggesting altered calcium-handling as a site for steroid action. The present study shows a small but significant decrease in islet total protein synthesis by dexamethasone that may involve some key protein(s) implicated in the release of insulin. Therefore, islet calmodulin and protein kinases and their substrates deserve further exploration. In this context, the actions of dexamethasone and other gluco- and mineralocorticoids in decreasing stimulated insulin release may be multifactorial. The present acute results produced by glucocorticoid treatment of islets in culture are in agreement with recent observations of reduced insulin response to glucose in mice treated with hydrocortisone [10], and indicate a possible role for adrenal steroids in the modulation of insulin release by secretagogues.

Acknowledgements. This work was supported by CONICIT, Venezuela, Grant No. 51-1171 and by the CDCH, UCV, Caracas, Venezuela. The technical assistance of Lic. A de Oliveira is gratefully acknowledged. Dr. Navas was a fellow from Universidad del Sulia, Maracaibo, Venezuela. We thank Merck Sharpe \& Dohme (Venezuela) for the supply of dexamethasone and prednisolone.

\section{References}

1. Barseghian G, Levine R (1980) Effect of corticosterone on insulin and glucagon secretion by the isolated perfused rat pancreas. Endocrinology 106: 547-552

2. Billaudel B, Sutter BCJ (1979) Direct effect of corticosterone upon insulin secretion studied by three different techniques. Horm Metab Res 11: 555-560

3. Coll-Garcia E, Gill JR (1969) Insulin release by isolated pancreatic islets of the mouse incubated in vitro. Diabetologia 5:61-66

4. Krebs HA, Henseleit K (1932) Untersuchungen über die Harnstoffbildung im Tierkörper. Hoppe Seylers Z Physiol Chem 210: $33-62$

5. Albano JDM, Ekins RP, Maritz G, Turner RC (1972) A sensitive, precise radioimmunoassay of serum insulin relaying on charcoal separation of bound and free hormone moieties. Acta Endocrinol 70: 487-609

6. Pierluissi J, Pierluissi R, Ashcroft SJH (1980) Effects of growth hormone on insulin release in the rat. Diabetologia 19:391-396

7. Ashcroft SJH, Bunce J, Lowry M, Hansen SE Hedeskov CJ (1978) The effect of sugars on (pro) insulin biosynthesis. Biochem J 174: $517-526$

8. De Pirro R, Green A, Yung-Chin Koa M, Olefsky JM (1981) Effects of prednisolone and dexamethasone in vivo and in vitro: studies of insulin binding, deoxy glucose uptake and glucose oxidation in rat adipocytes. Diabetologia $21: 149-153$

9. Billaudel B, Mathias PCF, Sutter BCJ, Malaisse WJ (1984) Inhibition by corticosterone of calcium inflow and insulin release in rat pancreatic islets. J Endocrinol 100: 227-233

10. Longano CA, Fletcher HP (1983) Insulin release after acute hydrocortisone treatment in mice. Metabolism 32: 603-608

Received: 4 November 1985

and in revised form: 19 November 1985

Dr. J.Pierluissi

Department of Physiology

Vargas School of Medicine

Universidad Central de Venezuela

Caracas

Venezuela 